\title{
Editorial
}

John M. Murkin MD FRCPC,* Donald H. Lee MD FRCPC $\dagger$

\section{Noninvasive measure- ment of cerebral blood flow: techniques and limitations}

In 1945, Seymour Kety and Carl Schmidt, working in Philadelphia, published a classic paper describing the results of their investigations assessing the efficacy of an inert gas $\left(\mathrm{N}_{2} \mathrm{O}\right)$ clearance method for the indirect measurement of mean cerebral blood flow (CBF) in animals and man. ${ }^{1}$ Their technique involved an ingenious application of the Fick principle as originally described in 1870. This demonstration, predicated in part on the recognition that CBF could be expressed in terms of unit weight of brain, i.e., $\mathrm{ml} \cdot 100 \mathrm{~g}^{-1} \cdot \mathrm{min}^{-1}$, enabled assessments of the cerebrovascular and metabolic status of whole brain to be made in vivo in the intact organism for the first time.

A subsequent modification involving the use of radioactive tracers (as suggested in the original report ${ }^{1}$ ) was described by Lassen and Munck in $1954 .^{2}$ The ensuing availability of compact scintillation detectors and microprocessor technology enabled measurements of $\mathrm{CBF}$ and cerebral metabolic rate for oxygen $\left(\mathrm{CMRO}_{2}\right)$ to be made readily, and in a wide variety of clinical situations. ${ }^{3}$

Expense, exposure to radioisotopes, the necessity for a steady-state, and the potentially complex analyses required to compensate for various methodological limitations, e.g., recirculation and extracerebral contamination, have limited widespread application of these techniques. However, despite these qualifications, the KetySchmidt technique remains the standard for the quantitative clinical assessment of global CBF and cerebral metabolic rate for oxygen $\left(\mathrm{CMRO}_{2}\right){ }^{4}$

The desirability of being able to evaluate CBF in a variety of physiological and pathological states has resulted in the tentative clinical application of various other methodologies aimed at assessing CBF. Amongst these were a thermovelocity technique which utilized a heat-sensitive jugular catheter, but which suffered from limited resolution and an inconsistent relationship between volume and velocity of flow, and which was

Departments of Anaesthesia* and Diagnostic Radiology, $\dagger$ University of Western Ontario, London, Ontario. influenced unpredictably by total jugular venous blood flow. ${ }^{5}$ Measurements of cerebral arterio-venous oxygen content difference have also been utilized as a gauge of $\mathrm{CBF},{ }^{6}$ but this is a qualitative measure, predicated upon a constant $\mathrm{CMRO}_{2}$ and reflecting only relative changes in $\mathrm{CBF}$. In addition, all of these measures require invasive instrumentation.

Most recently, Doppler sonography, originally used for the assessment of extracranial vessels, has been modified to allow measurement of flow velocities through intracerebral arteries (Transcranial Doppler - TCD). ${ }^{7}$ Using low frequency sound $(1-2.5 \mathrm{MHz})$ transmitted through thin areas of skull, e.g., the "temporal window" located above the zygomatic arch between ear and orbit, or foramina (foramen magnum, orbital foramina), direction-sensitive probes incorporating range gating can measure velocities in the basal arteries at selected depths inside the skull. With experience, this technique has the advantages of being fast, accurate, reproducible, and noninvasive, and is ideally suited for continuous, "real-time" assessments of the physiology of flow in major intracranial arteries, e.g., proximal middle cerebral artery - M1.

Whether this technique as currently configured is an appropriate substitute for other clinical methodologies for quantification of $\mathrm{CBF}$ is unclear. Absolute flow velocities measured with TCD vary with age, haematocrit, $\mathrm{PaCO}_{2}$, and regional cerebral metabolic activity, among other variables. ${ }^{8}$ There is an inconstant relationship between blood flow velocity and cerebral perfusion. While changes in MCA velocity correlate well with $\mathrm{CBF}$ changes, the velocities do not directly correlate with $\mathrm{CBF},{ }^{9,10}$ in part a reflection of inter-individual variation in the calibre of cerebral vessels being insonated. ${ }^{11}$ In addition, increases in TCD flow velocity correlate inversely with vessel diameter in the presence of cerebral vasospasm, but may be directly proportional to vessel diameter in the face of distal peripheral vasodilatation or cerebral hyperaemia, e.g., AV malformation. This presents a paradox, since increased flow velocity may represent either a consider- 
able increase or a drastic reduction in $\mathrm{CBF}$. As current TCD technology does not allow the determination of vessel calibre necessary for the calculation of crosssectional area and thus CBF, the clinical setting, and the use of ancillary techniques for the assessment of CBF, become important for the interpretation and analysis of TCD velocity data.

When TCD velocity data are employed to calculate cerebrovascular resistance, certain limitations should be recognized. The Gosling pulsatility index (peak systolic velocity-end diastolic velocity/mean velocity), or the Pourcelot resistance index (peak systolic-end diastolic/ peak systolic velocity), are dimensionless entities describing flow characteristics of the vessel being insonated. Vessels with high distal resistances have increased pulsatility and resistance indices. Unfortunately, there is no transcranial Doppler literature quantitating the level to which resistance must be increased before there is a change in the pulsatility index. However, if there is the same percentage change in both peak systolic and end-diastolic velocities such as can occur with vasodilatation, then the calculated resistance index would remain constant despite a decrease in distal vascular resistance. Certainly, there have been studies in an animal model with induced stenoses of peripheral arteries in which the pulsatility index was shown to be insensitive for the detection of stenosis. ${ }^{12}$ Similarly, in the assessment of renal arteries in vivo, the resistance index has been found to be insensitive, and misleadingly high, in normal patients without renal disease. ${ }^{13}$

Despite these provisos, the noninvasive, real-time nature of TCD, coupled with its unique ability to examine the physiological characteristics of cerebral blood flow, ${ }^{14}$ will open many new areas for clinical investigation. In this issue of the Journal the results of two such clinical studies are reported. Leon and Bissonnette ${ }^{15}$ employed TCD techniques to examine cerebrovascular responses to alterations in carbon dioxide tension in children during isoflurane or halothane anaesthesia. Kochs et al.$^{16}$ have employed TCD in conjunction with electroencephalographic (EEG) monitoring to assess continuously the influence of ketamine on neuronal activity and cerebrovascular haemodynamics. On the one hand, TCD allowed important measures of cerebral haemodynamics to be made in a paediatric group in whom more direct measures of CBF could hardly be justified, while on the other, the continuous measurement of MCA flow velocity allowed correlation to be made with changes in EEG activity. In both these studies the unique characteristics of TCD were deftly exploited. As with all such methodologies, however, the success of these endeavours is predicated not only upon the capabilities of the technique, but also upon an appreciation of its inherent limitations.

\section{La mesure de débit sanguin cérébral par techniques non invasives}

C'est en 1945 que Seymour Kety et Carl Schmidt de Philadelphie, publièrent les résultats de l'utilisation de la clairance d'un gaz inerte $\left(\mathrm{N}_{2} \mathrm{O}\right)$ dans le but de mesurer indirectement le débit sanguin cérébral moyen chez l'homme et l'animal. ${ }^{1}$ Leur méthode mettait en application le principe décrit par Fick en 1870 et permettait dorénavant de mesurer les conditions métaboliques et vasculaires globales du cerveau intact in vivo, le débit sanguin étant exprimé en fonction de la masse cérébrale : $\mathrm{ml} \cdot 100 \mathrm{~g}^{-1} \cdot \mathrm{min}^{-1}$. En 1954, Lassen et Munk modifièrent la méthode en utilisant des substances radioactives comme traceur ${ }^{2}$ tel que suggéré par Kety et Schmidt. Couplé à l'usage de petits détecteurs de radioactivité et de l'électronique, la méthode ainsi modifiée permis la mesure du métabolisme et du débit sanguin cérébral dans une foule de conditions cliniques. ${ }^{3}$

Toutefois, ses coûts, l'exposition à des radio-isotopes, la nécessité d'avoir des conditions en équilibre et les analyses complexes nécessaires pour contourner ses limites telles la recirculation des traceurs et la contamination extracérébrale ont empêché l'application de cette méthode sur un grande échelle, même si elle demeure l'étalon de la mesure globale du débit sanguin cérébral (CBF) et du métabolisme cérébral de l'oxygène $\left(\mathrm{CMRO}_{2}\right){ }^{4}$

Le besoin de pouvoir mesurer facilement le $\mathrm{CBF}$ associé à diverses conditions physiologiques et pathologiques a contribué aux tentatives d'application clinique d'autres méthodes de mesure. La technique de thermovélocité impliquait l'usage d'une sonde thermique jugulaire; sa résolution était toutefois limitée et la relation entre le volume et la vitesse du flux n'était pas constante de plus, le débit sanguin jugulaire total pouvait influencer les résultats de manière imprévisible. ${ }^{5}$ La mesure différentielle du contenu en oxygène du sang artériel et veineux cérébral a servi d'estimé qualitatif du $\mathrm{CBF}^{6}$ qui présume de la constance du $\mathrm{CMRO}_{2}$; elle ne reflète que les changements du CBF et requiert la pose de cathéters endovasculaires.

Récemment, on a modifié la sonographie Doppler qui avait d'abord été utilisée dans l'évaluation des vaisseaux extracrâniens pour lui permettre de mesurer la vitesse du flux des artères intracérébrales («Transcranial Doppler»-TCD). ${ }^{7}$ Cette méthode emploie des sondes directionnelles qui émettent des sons de basses fréquences 
(1-2,5 MHz) à travers les zones minces du crâne telle la «fenêtre temporale» au dessus de l'arcade zygomatique entre l'oreille et l'orbite ou à travers les divers trous du crâne (trou occipital, trou orbitaire). Elle permet ainsi de mesurer la vitesse du flux dans les artères de la base du cerveau à diverses profondeurs à l'intérieur du crâne. Avec de la pratique, cețe technique non invasive permet la mesure immédiate, rapide, précise, et reproductible de la physiologie de la circulation des artères cérébrales majeures dont l'artère cérébrale moyenne proximale ou M1.

Il reste à voir si cette méthode pourra se substituer aux autres méthodes de mesure du CBF. Avec le TCD, les vitesses absolues du flux varient en fonction de l'âge, de l'hématocrite, de la $\mathrm{PaCO}_{2}$, de l'activité cérébrale régionale etc. ${ }^{8}$ Toutefois, la relation entre la vitesse du flux sanguin et la perfusion cérébrale est variable : même s'il y a corrélation entre les changements de vélocité du flux de M1 et les changements de CBF, il n'y a pas de corrélation directe entre vélocité du flux et $\mathrm{CBF}^{9,10}$ et cela est dû en partie aux variations individuelles dans le calibre des vaisseaux cérébraux. ${ }^{11}$ De plus, en présence de vasospasme, l'augmentation de la vitesse du flux mesurée au TCD est inversement proportionnelle au calibre des vaisseaux alors qu'avec de la vasodilatation périphérique ou de l'hypérémie (ex.: malformation artério-veineuse), cette relation est directement proportionnelle. Voilà un troublant paradoxe où une grande vitesse du flux peut être associée à un $\mathrm{CBF}$ très élevé ou au contraire, sévèrement limité. Comme le TCD ne peut pour le moment mesurer le calibre des vaisseaux observés dans le but de calculer le $\mathrm{CBF}$, le contexte clinique et certaines techniques d'appoint vont devoir influencer l'interprétation de ses données sur la vitesse du flux.

D'ailleurs, on doit reconnaître les limites de l'utilisation de la vélocité du flux dans le calcul des résistances cérébrovasculaires. Ainsi, l'indice de pulsativité de Gosling (vélocité systolique maximale-vélocité en fin de diastole/vélocité moyenne) et l'indice de résistance de Pourcelot (vélocité systolique maximale-vélocité en fin de diastole/vélocité systolique maximale) n'ont aucune dimension physique et décrivent le caractère du flux du vaisseau examiné. Les vaisseaux aux résistances distales importantes ont une pulsativité et un indice de résistance élevé. Malheureusement, la littérature sur le TCD ne fait pas mention des nivaux de résistance à atteindre avant que ne change l'indice de pulsativité. Toutefois, si la vasoconstriction devait à l'instar de la vasodilatation entraîner des modifications comparables des vélocités systoliques maximales et diastoliques, l'indice de résistance calculé demeurerait le même malgré une diminution de la résistance vasculaire distale. D'ailleurs certaines études animales ont montré que l'indice de pulsativité n'est pas un moyen de détection sensible de sténoses des artères périphériques ${ }^{12}$ de plus, dans l'évaluation in vivo d'artères rénales, l'indice de résistance s'est avéré être peu fiable et injustement élevé chez les patients aux reins normaux. ${ }^{13}$

La nature non invasive et instantanée du TCD de même que la possibilité qu'il offre d'observer la physiologie du CBF lui confère, malgré ses limites, une place dans l'arsenal de la recherche clinique. Ce numéro du Journal contient deux articles traitant de l'usage de cette technologie. Léon et Bissonnette s'en sont servi pour observer l'effet cérébrovasculaire de variations de la $\mathrm{PaCO}_{2}$ chez des enfants anesthésiés à l'halothane ou à l'isoflurane ${ }^{15} \mathrm{ce}$ qui en soit est important mais pas au point de justifier l'usage de mesures plus directes du CBF. Koch et ses collègues ${ }^{16}$ l'ont utilisé de pair avec l'électroencéphalographie afin d'observer en continu, l'effet de la kétamine sur l'activité neuronale et cérébrovasculaire, permettant d'établir une corrélation entre la vitesse du flux sanguin dans l'artère cérébrale moyenne et l'activité électroencéphalographique. Les auteurs de ces deux articles ont su mettre à profit les avantages stratégiques du TCD. N'oublions pas toutefois que le succès d'études employant une technologie nouvelle réside autant dans l'exploitation de son potentiel que dans la reconnaissance de ses limites.

\section{References}

1 Kety SS, Schmidt CF. The determination of cerebral blood flow in man by the use of nitrous oxide in low concentrations. Am J Physiol 1945; 143: 53-66.

2 Lassen NA, Munck $O$. The cerebral blood flow in man determined by the use of radioactive krypton. Acta Phys Scand 1954; 33: 30-49.

3 Murkin JM, Farrar JK, Tweed WA, McKenzie FN, Guiraudon $G$. Cerebral autoregulation and flow/ metabolism coupling during cardiopulmonary bypass: the influence of $\mathrm{PaCO}_{2}$. Anesth Analg 1987; 66: 825-32.

4 Siesjo $B D$. Circulation and oxygen consumption in the brain. In: Siesjo BK. Brain Energy Metabolism. New York: Wiley J \& Sons 1978: 56-100.

5 Branthwaite MA. Cerebral blood flow and metabolism during open-heart surgery. Thorax 1974; 29: 633-8.

6 Wollman $H$, Stephen $G W$, Clement AJ. Cerebral blood flow in man during extracorporeal circulation. $\mathrm{J}$. Thorac Cardiovasc Surg 1966; 52: 558-64.

7 Aaslid $R$, Markwalder $T$, Nornes $H$. Noninvasive transcranial Doppler ultrasound recording of flow velocities in basal cerebral arteries. J Neurosurg 1982; 57: 769-74.

8 Caplan LR, Brass LM, DeWitt LD et al. Transcranial Doppler ultrasound: present status. Neurology 1990; 40: 696-700. 
9 Kontos HA. Validity of cerebral arterial blood flow calculations from velocity measurements. Stroke 1989; 20: 1-3.

10 Bishop CCR, Powell S, Rutt D, Browse NL. Transcranial doppler measurement of middle cerebral artery flow velocity: a validation study. Stroke 1986; 17: 913-5.

11 Gabrielsen TO, Greitz T. Normal size of the internal carotid, middle cerebral and anterior cerebral arteries. Acta Radiol 1970; 10: 1-10.

12 Baker AR, Evans DH, Prytherch DR et al. Some failings of pulsatility index and damping factor. Ultrasound Med Biol 1986; 12: 875-81.

13 Cronan J, Barnes B, Scola FH, Schepps B. Renal resistive index as a determinant of presence of intrinsic renal disease. Radiology 1990; 177: 229.

14 Murkin JM, Lee DH. Transcranial Doppler verification of pulsatile cerebral blood flow during cardiopulmonary bypass. Anesth Analg 1991; 72: S194.

15 Leon JR, Bissonnette B. Cerebrovascular responses to carbon dioxide in children anaesthetized with halothane and isoflurane. Can J Anaesth 1991; (this issue).

16 Kochs E, Werner C, Hoffman WE, Mollenberg $O$, Schulte am Esch $J$. Concurrent increases in brain electrical activity and intracranial blood flow velocity during low-dose ketamine anaesthesia. Can J Anaesth 1991; (this issue). 